University of Nebraska - Lincoln

DigitalCommons@University of Nebraska - Lincoln

Faculty Publications: Department of Entomology

Entomology, Department of

October 2000

\title{
Atrazine induction of cytochrome P450 in Chironomus tentans larvae
}

Francisca Miota

University of Nebraska-Lincoln

Blair Siegfried

University of Nebraska-Lincoln, bsiegfried1@ufl.edu

Michael E. Scharf

University of Nebraska-Lincoln

Michael J. Lydy

Wichita State University, Wichita, KS

Follow this and additional works at: https://digitalcommons.unl.edu/entomologyfacpub

Part of the Entomology Commons

Miota, Francisca; Siegfried, Blair; Scharf, Michael E.; and Lydy, Michael J., "Atrazine induction of cytochrome P450 in Chironomus tentans larvae" (2000). Faculty Publications: Department of Entomology. 53.

https://digitalcommons.unl.edu/entomologyfacpub/53

This Article is brought to you for free and open access by the Entomology, Department of at DigitalCommons@University of Nebraska - Lincoln. It has been accepted for inclusion in Faculty Publications: Department of Entomology by an authorized administrator of DigitalCommons@University of Nebraska - Lincoln. 


\title{
Atrazine induction of cytochrome P450 in Chironomus tentans larvae
}

\author{
Francisca Miota ${ }^{a}$, Blair D. Siegfried ${ }^{a *}$, Michael E. Scharf ${ }^{a}$, \\ and Michael J. Lydy ${ }^{\mathrm{b}}$ \\ a Department of Entomology, 202 Plant Industry Building, University of Nebraska, Lincoln, NE 68583, USA \\ b Department of Biological Science, Wichita State University, Wichita, KS 67260, USA \\ *Corresponding author. Tel.: 402-472-211; fax: 402-472-1237.
}

\begin{abstract}
Cytochrome P450-dependent aldrin epoxidation was characterized in third instar larvae of the aquatic midge, Chironomus tentans. Optimal in vitro assay conditions for the epoxidase were $\mathrm{pH} 7.6$ and $31^{\circ} \mathrm{C}$. Activity was linear up to $40 \mathrm{~min}$ of incubation time and $0.5 \mathrm{mg}$ microsomal protein per incubation. The activity was concentrated in the microsomal fraction of whole body homogenates and was NADPH-dependent. The effect of atrazine exposure on aldrin epoxidase was measured to determine if this herbicide induces cytochrome P450-dependent activity. Comparisons of control and atrazine-exposed midges indicated increased epoxidase activity as a result of atrazine exposure, and a $45 \mathrm{kDa}$ protein of increased intensity was observed after SDS-PAGE of microsomal protein. The molecular weight of this protein was similar in size to cytochrome P450 enzymes reported for other insects. Heme staining of SDS-PAGE gels and immunochemical studies using a Drosophila melanogaster anti-P450 polyclonal antiserum, further support the cytochrome P450 nature of this inducible $45 \mathrm{kDa}$ protein.
\end{abstract}

Keywords: Atrazine, Induction, Cytochrome P450, Chironomus tentans

\section{Introduction}

One of the larger families of cytochrome P450-dependent microsomal monooxygenases are the hemethiolate membrane-associated proteins with a molecular weight between 45$60 \mathrm{kDa}$. This enzyme system plays a key role in the metabolism of a wide range of endogenous and exogenous substances. Cytochrome P450 enzymes are inducible through a mechanism shown to be largely controlled at the transcriptional level (Batard et al., 1997). The ecological and physiological significance of induction is uncertain, although with insects, induction is believed to provide versatility in the adaptation of insects to their environment (Terriere, 1984; Ahmed et al., 1986).

Induction of the P450 system can have important consequences concerning the ability of insects to tolerate exposure to pesticides. For example, the herbicide atrazine has been reported to enhance the toxicity of selected insecticides to Drosophila melanogaster Meigen, Musca domestica L. and larvae of Aedes aegypti L. (Lichtenstein et al., 1973). Recent$1 y$, it has been shown that larvae of the aquatic midge, Chironomus tentans (Fabricius), when exposed to atrazine in combination with several organophosphate insecticides, resulted in greater than additive toxicity (Lindstrom and Lydy, 1997). The synergistic effects observed by Pape-Lindstrom and Lydy suggest that processes involved with oxidation of the organophosphate molecule to the more toxic oxon metabolite may be enhanced in the atrazineexposed midges. The oxon metabolite of phosphorothioate organophosphates is a stronger acetylcholinesterase inhibitor than the parent compound. If a higher body residue of the oxon metabolite results from P450 induction, such a process may account for the greater than additive toxicity. 
Since pesticides, such as atrazine and organophosphate insecticides are so widely used in agricultural systems throughout the Midwest, there is a strong likelihood that combinations of these pesticides co-occur in the environment. Atrazine is commonly detected (Thurman et al., 1992), however most Midwestern streams are not routinely monitored for insecticides. It is therefore important that the mechanism responsible for this relationship be further investigated. The main objective of the present study was to determine if atrazine can induce cytochrome P450-dependent microsomal monooxygenases, thereby providing a possible explanation for the reported phenomena of atrazine-insecticide synergism in C. tentans.

\section{Materials and methods}

\subsection{Insects}

C. tentans larvae were obtained from Wichita State University, Department of Biological Sciences, and were reared according to US EPA protocols (US Environmental Protection Agency, 1991), for static cultures with the slight modification that the cultures were maintained with a mixture of developmental stages.

\subsection{Chemicals}

Technical grade atrazine (99\% purity) was purchased from SUPELCO (Bellefonte, PA). Aldrin and dieldrin were obtained from Crescent Chemical (Hauppauge, NY) and NADPH (tetrasodium salt, grade III), NADH (disodium salt, grade III), glucose 6-phosphate, and glucose 6-phosphate dehydrogenase (Bakers yeast) were obtained from Sigma Chemical (St. Louis, MO). Electrophoresis reagents were purchased from Bio-Rad laboratories (Hercules, CA). All other chemical and biochemical reagents were purchased from Sigma Chemical (St. Louis, MO) and solvents were of reagent grade or better.

\subsection{Protein preparations}

Whole body homogenates of midge larvae were pre-pared in $150 \mathrm{mM}$ potassium phosphate buffer, $50 \mathrm{mM}$ sucrose $(\mathrm{pH} 7.4)$, with a Teflon glass Potter-Elvehjem type homogenizer. For routine activity measurement, homogenates were centrifuged at $10000 \mathrm{~g}$ for $20 \mathrm{~min}$, in a microcentrifuge, and the supernatant removed for use in enzyme assays. For other experiments, this $10000 \mathrm{~g}$ supernatant was further centrifuged at $100000 \mathrm{~g}$ for $1 \mathrm{~h}$ in a Beckman TL 100 ultracentrifuge (Palo Alto, CA). Protein concentration for all preparations was determined with a commercially available bicinchoninic acid protein assay (Pierce, Rockford, IL) according to manufacturer's instructions, using bovine serum albumin as the standard.

\subsection{Activity measurements}

Cytochrome P450-dependent epoxidation was measured by quantifying the conversion of aldrin to its epoxide, dieldrin, using the method described by Siegfried and Mullin (1988). The incubation mixture $(0.5 \mathrm{ml})$ for aldrin epoxidase with final concentrations in $0.1 \mathrm{M}$ potassium phosphate buffer $(\mathrm{pH} 7.4)$ included aldrin $(0.05 \mathrm{mM})$ introduced in $5 \mu \mathrm{l}$ ethanol, NADPH $(1.0 \mathrm{mM})$ and $100 \mu \mathrm{l}$ of the enzyme extract. After a $1 \mathrm{~min}$ preincubation at $31^{\circ} \mathrm{C}$, NADPH was added and the reaction al-lowed to proceed for 20 min with shaking. A combined 2,2,4-trimethylpentane extract $(2 \times 0.5 \mathrm{ml})$ of the assay mixture was dried over anhydrous sodium sulfate and analyzed with dieldrin standards by gas-liquid chromatography on a $30 \mathrm{~m}$ by $0.25 \mathrm{~mm}$ i.d. RTX5 glass capillary column (Restek, Bellefonte, PA) containing a 0.25 am film of cross-bonded 95\% dimethyl-5\% diphenyl polysiloxane. A Shimadzu Model 14-A gas chromatograph (Kyoto, Japan) with a 63Ni electron capture detector, $\mathrm{N}_{2}$ at $2 \mathrm{ml} / \mathrm{min}$, and a column temperature of $180^{\circ} \mathrm{C}$ was used for all analyses. Peak retention times averaged $4.5 \mathrm{~min}$. for aldrin and 7.9 min for dieldrin. Activities based on peak areas were calculated relative to controls lacking NADPH.

\subsection{Induction assays}

Midges were exposed to atrazine by maintaining groups of 30-40 third instar larvae in 1 liter beakers at room temperature and ambient lighting. Approximately $2 \mathrm{~cm}$ of sediment was added to each beaker prior to introducing midges. An experiment consisted of 1 control (without atrazine) and two experimental beakers, and each experiment was repeated 3 times. After acclimation of the water to the proper temperature, $1 \mathrm{ml}$ of 10 or $0.1 \mathrm{mg} /$ $\mathrm{ml}$ atrazine in ethyl acetate was added to the experimental beakers, while $1 \mathrm{ml}$ of the solvent was added to the controls. No mortality was observed among the larvae kept in control beakers. After 80 and $160 \mathrm{~h}$ of exposure, 20 midges were collected from each beaker for assay of aldrin epoxidation.

\subsection{Gel electrophoresis and immunodetection}

SDS polyacrylamide gel electrophoresis (PAGE) was performed in a vertical electrophoresis unit (Bio-Rad Mini-Protean II, Richmond, CA), using a 10\% separating gel and 
4\% stacking gel with a discontinuous Trisglycine buffer system. Samples of microsomes in $150 \mathrm{mM}$ potassium phosphate with 50 $\mathrm{mM}$ sucrose were diluted 1:1 with SDS sample buffer and heated at $95^{\circ} \mathrm{C}$ for $4 \mathrm{~min}$. Individual wells were loaded with a volume of microsomal protein containing $30 \mu \mathrm{g}$. Gels were run at constant voltage for $45 \mathrm{~min}$ and proteins visualized by staining the gels for $0.5 \mathrm{~h}$ with $0.1 \%$ Coomassie blue R-250 (Bio-Rad) in fixative $(40 \%$ methanol, $0.5 \%$ acetic acid) or transferred to nitrocellulose membranes (Amersham Life Science, England) for immunodetection using Bio-Rad Mini Trans-Blot Cell. Transfer buffer consisted of $25 \mathrm{mM}$ Tris, 192 $\mathrm{mM}$ glycine and 20\% methanol, and the membranes were probed with poly-clonal ascites antiserum to D. melanogaster P450 (Sunseth et al., 1989). Detection followed the instructions for the Bio-Rad alkaline phosphatase substrate kit.

\subsection{Heme staining}

The electrophoresis procedure was modified to visualize the heme-containing proteins. PAGE gels were prepared as described previously except that SDS was omitted from the gels (Thomas et al., 1976). Prior to loading, the gels were run overnight at $1 \mathrm{~mA}$ to remove excess ammonium persulfate and to allow SDS from the running buffer to enter the gels (Thomas et al., 1976). Microsomal protein $(50 \mu \mathrm{g})$ was diluted $1: 1$ in sample buffer and incubated for $5 \mathrm{~min}$ at $70^{\circ} \mathrm{C}$ before being loaded into individual wells. ( $\beta$-Mercaptoethanol was omitted from the sample buffer, since it inhibits the peroxidase staining reaction (Welton and Aust, 1974). Gels were run at a constant $120 \mathrm{~V}$ for $2 \mathrm{~h}$ at $4^{\circ} \mathrm{C}$. Bands with peroxidase activity were visualized following the method by Butler and Lachance, 1987 by staining with $2 \mathrm{mM} N, N, N^{\prime} N^{\prime}$-tetramethyl-p-phenylenediamine (TMPD) in 0.03\% hydrogen peroxide.

\section{Results}

\subsection{Optimal conditions for in vitro measure- ment}

Aldrin epoxidase from whole body homogenates of $C$. tentans larvae exhibited optimal activity at $\mathrm{pH} 7.6$ in potassium phosphate/ sucrose buffers (Fig. 1(A)). Epoxidation of aldrin at $\mathrm{pH} 7.6$ proceeded maximally at $31^{\circ} \mathrm{C}$ (Fig. 1(B)), was linear with time up to at least 40 min (Fig. 1(C)) and with increasing protein up to at least $0.4 \mathrm{mg} / \mathrm{ml}$, after which time the rate of further epoxidation decreased (Fig. 1(D)). The addition of $0.4 \mathrm{mg}$ of protein/ incubation was sufficient to yield representative activity. These results are consistent with those reported by Estenik and Collins (1979) who conducted similar optimization of aldrin epoxidase from Chironomus riparius larvae.

\subsection{Subcellular localization}

Differential centrifugation of $C$. tentans whole body homogenates and analysis of the subcellular distribution of epoxidase activity demonstrated that this activity fractionated preferentially into a high-speed pellet (Fig. 2(A)) that normally contains the microsomal fraction. Over $90 \%$ of the original homogenate activity was re-covered, of which, $87 \%$ precipi-
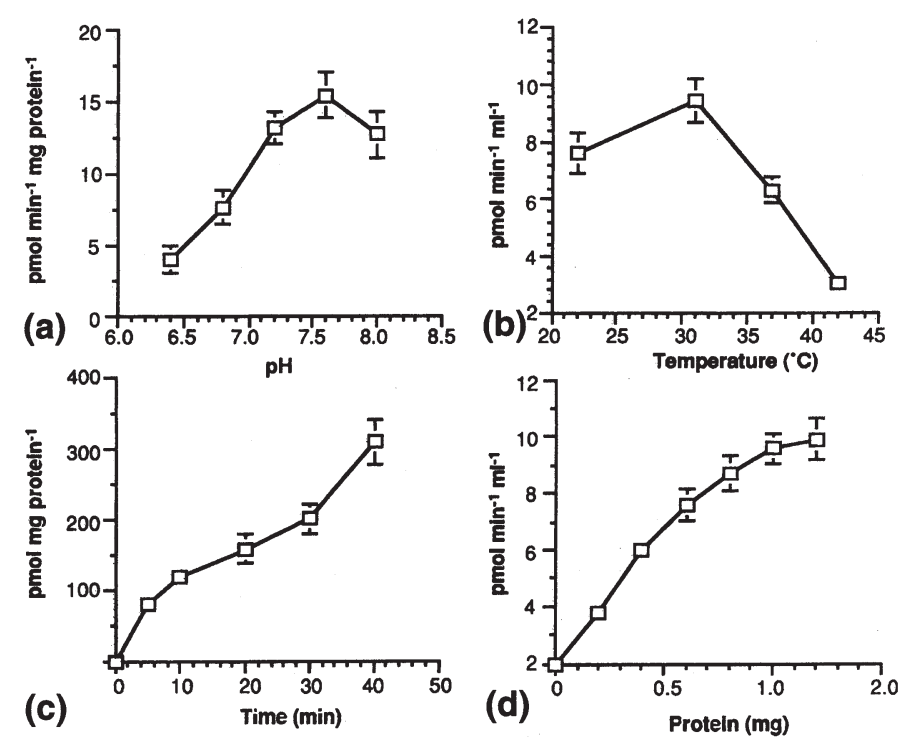

Fig. 1. Effect of $\mathrm{pH}(\mathrm{A})$, temperature (B), incubation time (C), and protein concentration (D), on NADPH-dependent aldrin epoxidation in the $10000 \mathrm{~g}$ supernatnant of whole body homogenates of C. tentans larvae. Bars indicate means $\pm \mathrm{SE}$ of nine determinations. 

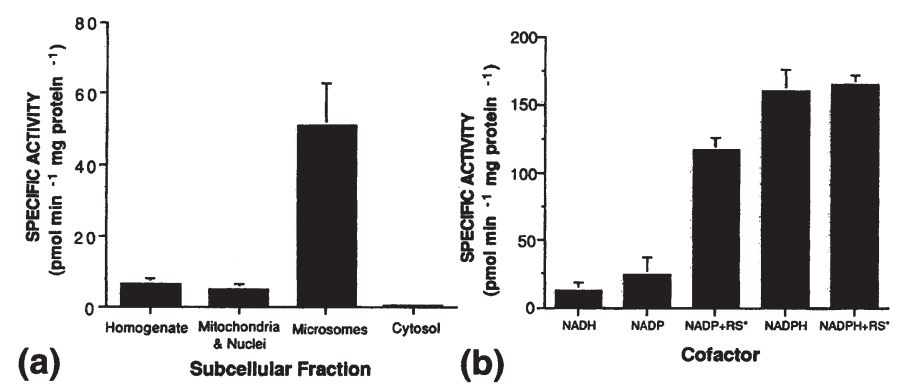

Fig. 2. Subcellular distribution (A) and cofactor requirements (B) of C. tentans aldrin epoxidase activity ( ${ }^{*} \mathrm{RS}$ refers to NADPH regenerating system; see text for details).

tated at $100000 \mathrm{~g}$. Less than $10 \%$ of this total activity remained soluble after $1 \mathrm{~h}$ at 100,000 $\mathrm{g}$, which is likely to represent contamination from the microsomal pellet. Hence, this epoxidase is primarily a microsomal cytochrome P450 enzyme rather than representing mitochondrial or nuclear activity.

\subsection{Co-factor requirements}

The electron transport system of cytochrome P450 monooxygenases requires NADPH as the initial electron donor in the sequence of reactions leading to the oxidized substrate (Hodgson, 1985). In C. tentans, the epoxidation of aldrin to dieldrin proceeded maximally when $\beta-N A D P H$ was provided either by direct addition or generated by glucose 6-phosphate dehydrogenase in the assay mixture. Approximately $13 \%$ of the control activity was obtained when NADP+ was provided without a regenerating system (Fig. 2(B)), suggesting that some level of endogenous dehydrogenases activity was present in the insect homogenates (Wilkinson and Brattsten, 1972). The addition of NADH to the system supported approximately $7 \%$ of control activity. The ability of NADH to support cytochrome P-450 catalyzed reactions has been reported for other

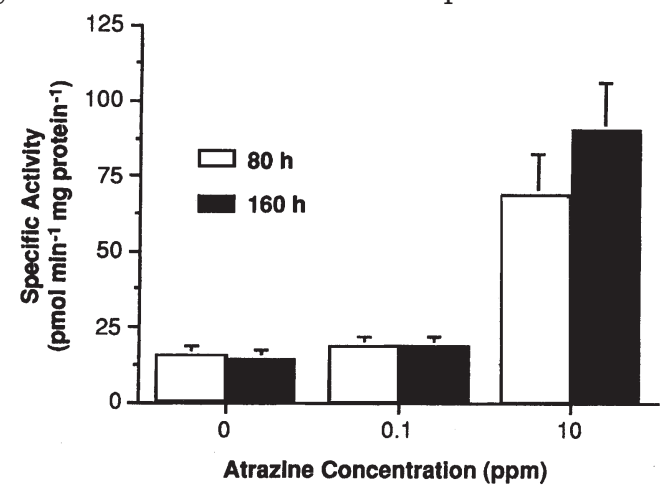

Fig. 3. Induction of C. tentans cytochrome P450-dependent aldrin epoxidase activity by 80 and $160 \mathrm{~h}$ exposures to atrazine at 0.1 and $10 \mathrm{ppm}$. Bars indicate standard error derived from the mean of three replicate experiments with three determinations for each experiment. insect groups, and it has been proposed that a Cytochrome b5 electron system may be functioning to supply reducing equivalents to Cytochrome P450 (Agosin, 1985).

\subsection{Atrazine induction experiments}

The exposure of midges to $10 \mathrm{ppm}$ of atrazine in solution for 80 and $160 \mathrm{~h}$ resulted in increases of aldrin epoxidase activity of 4and 9-fold, respectively (Fig. 3). Induction of aldrin epoxidase was not observed at $0.1 \mathrm{ppm}$ atrazine for either exposure period.

\subsection{SDS-PAGE}

The electrophoretic profile of microsomal proteins from control and atrazine induced midges is shown in Fig. 4. Similar banding patterns were noted for both control and induced preparations, except for a single protein band of approximately $45 \mathrm{kDa}$, which exhibited higher intensity in the atrazinetreated midges (Fig. 4). Electrophoresis of microsomal preparations from atrazine treated and control midges were also stained for heme-related peroxidase activity. An electromorph with peroxidase activity at $45 \mathrm{kDa}$ appeared in both treated and untreated larvae, but exhibited higher intensity in the atrazine-exposed midges.

\subsection{Immunodetection}

Western blots of microsomal protein from atrazine induced and control midges crossreacted with a $D$. melanogaster anti-P450 polyclonal antibody at a similar position to the inducible protein band detected at 45 $\mathrm{kDa}$ (Fig. 5). This band was recognized with higher signal intensity with atrazine-induced microsomes.

\section{Discussion}

Results from our experiments indicate that aldrin epoxidase from third instar $C$. tentans 

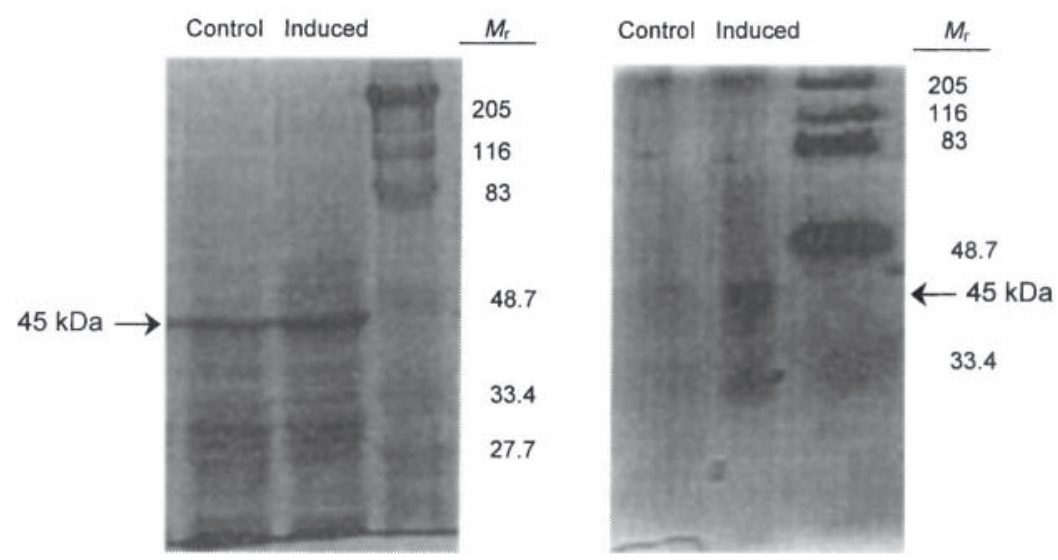

Fig. 4. SDS-PAGE of C. tentans microsomal proteins front control and atrazine-induced preparations stained with coomassie (A) and heme staining (B) techniques.

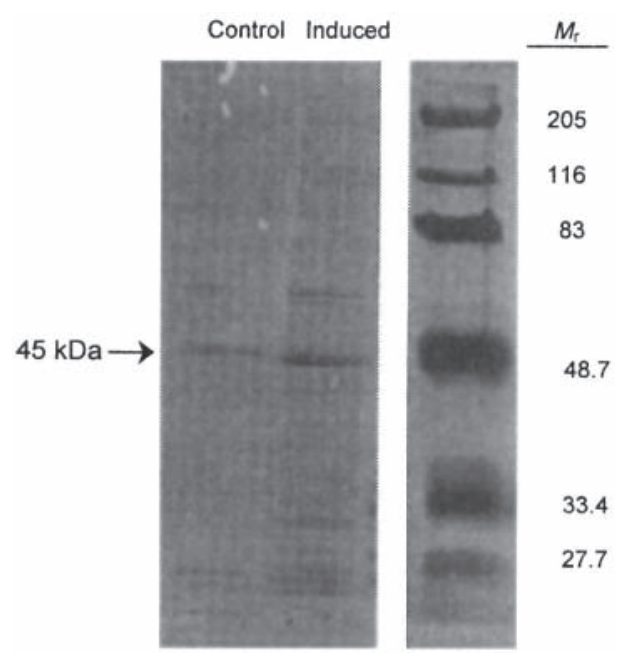

Fig. 5. Immunoblot of microsomal cytochrome P450 from control and atrazine induced midge larvae as recognized by a Drosophila P450 antibody.

larvae is catalyzed by a microsomal cytochrome P450 and that the enzyme is induced by atrazine. Exposure of midge larvae to atrazine at $10 \mathrm{ppm}$ resulted in significantly increased P450-dependent aldrin epoxidase activity relative to unexposed midges. Comparisons of SDS-PAGE of microsomal proteins from control and induced midges identified a protein band of increased intensity with a molecular weight of $45 \mathrm{kDa}$. Similar enhancement was observed in a heme-containing protein as evidenced by heme staining of SDS-PAGE gels. This band was also recognized by a polyclonal antiserum raised against P450 from $D$. melanogaster, although it is possible that this band is composed of multiple proteins.

These results taken together suggest that atrazine induces a specific P450 isozyme in C. tentans. Atrazine induction of cytochrome P450 has been previously reported in rats
(Ugazio et al., 1991) rainbow trout, the cabbage moth (Egaas et al., 1993) and recently in southern armyworms (Kao et al., 1995). Terriere (1984) suggested that if the enzyme system involved in the de-gradation of xenobiotics in insects is similar in most respects to that of higher animals, it must involve a recognition system wherein exogenous chemicals in the insect's environment can stimulate the production of the enzymes that degrade them. Although atrazine metabolism in insects has not been examined, metabolism studies in vertebrates indicate that primary detoxification in these systems involves $\mathrm{N}$-dealkylation reactions catalyzed by cytochrome P450-dependent monooxygenases (Gojmerac and Kniewald, 1989; Khan and Foster, 1976; Adams et al., 1990; Dauterman and Muecke, 1973).

Atrazine is the second most widely used pesticide in North America, with over 85 million pounds a.i. applied annually in the (U.S. Environmental Protection Agency, 1994; Solomon et al., 1996) and is a common contaminant of Midwestern streams and lakes (Thurman et al., 1992; Goolsby et al., 1993). It should be noted that the atrazine concentrations used in this investigation are much higher than those reported when atrazine is detected as a surface water contaminant. However, these studies represent exposures to aqueous solutions of atrazine and may not reflect the same levels or duration of exposure under field conditions. It should also be noted that environmental exposure to atrazine may involve simultaneous exposure to other agrochemicals, particularly compounds used in insect pest management. Carbamate, organophosphate and pyrethroid insecticides are commonly used for controlling a number of agriculturally important pest insects during the same period of the growing season when atrazine usage is highest. As a result, there is a strong likelihood that combinations of these 
pesticides co-occur in the environment, and therefore, the combined effects of these pesticides should be considered.

Herbicide-insecticide mixtures have been reported to affect organisms in different ways. Some interactions result in enhancing toxicity (Lindstrom and Lydy, 1997; Lichtenstein et al., 1979) while others reduce toxicity (Kao et at., 1995). These findings indicate the complex nature of the underlying mechanisms by which organ-isms tolerate exposure to mixtures of xenobiotics in their environment. Therefore, it is likely that the toxicity of a pesticide mixture is more complex than a simple "concentration addition" or a "response addition" model typically used for predicting the potential impact of mixtures in aquatic systems (Broderius et al., 1995; McCarty et al., 1992; Dawson and Wilke, 1991).

\section{Acknowledgements}

The authors acknowledge the technical support of Terrence Spencer and the critical reviews of Dr. Kenneth Pruess. Polyclonal P450 antiserum was generously provided by Dr. L.C. Waters, Oakridge National Laboratory. Support for this project was through the University of Nebraska Hatch Project NEB 17071. It is published with approval of the Director as Journal Series paper 12460, Nebraska Agricultural Research Division, and contribution number 1012 of the Department of Entomology, University of Nebraska-Lincoln.

\section{References}

Adams, N.H., Levi, P.E., Hodgson, E., 1990. In vitro studies of the metabolism of atrazine, simazine, and terbutryn in several vertebrate species. J. Agric. Food Chem. 38, 1441-1447.

Agosin, M., 1985. Role of microsomal oxidations in insecticide degradation. In: Kerkut, G.A., Gilbert, L.I. (Eds.), Comprehensive Insect Physiology, Biochemistry and Pharmacology, vol. 12. Pergamon, Elmsford, New York, pp. 647-712.

Ahmad, S., Brattsten, L.B., Mullin, C.A., Yu, S.J., 1986. Enzymes involved in the metabolism of plant allelochemicals. In: Brattsten, L.B., Ahmad, S. (Eds.), Molecular Aspects of InsectPlant Association. Plenum, New York, pp. 73151.

Batard, Y., Schalk, M., Pierre], M.A., Zimmerlin, A., Durst, F., Reichhart, D.W., 1997. Regulation of the cinnamate 4-hydrolase in (CYP733A1) Jerusalem artichoke tubers in response to wounding and chemical treatments. Plant Physiol. 113, 951-959.

Broderius, S.J., Khal, M.D., Hoglund, M.D., 1995. Use of toxic response to define the primary mode of toxic action for diverse industrial or- ganic chemicals. Environ. Toxicol. Chem. 14, 1591-1605.

Butler, M.J., Lachance, M.A., 1987. The use of $N, N, N, N$-tetramethylphenylenediamine to detect peroxidase activity on polyacrylamide electrophoresis gels. Anal. Biochem. 162, 443-445.

Dauterman, W.C., Muecke, W., 1973. In vitro metabolism of atrazine by rat liver. Pestic. Biochem. Physiol. 4, 212-219.

Dawson, D.A., Wilke, T.S., 1991. Evaluation of the frog embryo teratogenesis assay: Xenopus (FETAX) as a model system for mixture toxicity hazard assessment. Environ. Toxicol. Cliem. 10, 941-948.

Egaas, E., Skaare, J.U., Svendsen, N.O., Sandvik, M., Falls, J.G., Dauterman, W.C., Collier, T.K., Netland, J., 1993. A comparative study of effects of atrazine on xenobiotic metabolizing enzymes in fish and insects and of the in vitro phase II atrazine metabolism in some fish, insects, mammals and one plant species. Comput. Biochem. Physiol. C 106, 141-149.

Estenik, J.F., Collins, W.J., 1979. In vivo and in vitro studies of mixed function oxidase in an aquatic insect, Chironomus riparius. In: Khan, M.A.Q., Lech, J.J., Menn, J.J. (Eds.), Pesticide and Xenobiotic Metabolism in Aquatic Organisms. ACS symposium Series 99, Washington, DC, pp. 349-370.

U.S. Environmental Protection Agency, 1991. Methods for measuring the acute toxicity of effluents and receiving waters to freshwater and marine organisms, EPA-600-4-90-027, Washington, DC.

U.S. Environmental Protection Agency, 1994. Pesticides industry sales and usage, 1992 and 1993 market estimates, EPA 733-K-94-001.

Gojmerac, T., Kniewald, J., 1989. Atrazine biodegradation in rats. A model for mammalian metabolism. Bull. Environ. Contam. Toxicol. 43, 199-206.

Goolsby, D.A., Battaglin, W.A., Thurman, E.M., 1993. Occurrence and transport of agricultural chemicals in the Mississippi River baxsin July through August 1993, USGS Circular 11120-C. US Geological Research Center, Columbia, MO.

Hodgson, E., 1985. Microsomal mono-oxygenises, In: Kerkut, G.A., Gilbert, L.I. (Eds.), Comprehensive Insect Physiology, Biochemistry and Pharmacology, vol. 11. Pergamon, Elmsford, New York, pp. 231-255.

Kao, L.M., Wilkinson, C.F., Brattsten, L.B., 1995. In vivo effects of $2,4-\mathrm{D}$, and atrazine on cytochrome P-450 and insecticide toxicity in Southern armyworm (Spodoptera eridania) larvae. Pestic. Sci. 45, 331-334.

Khan, S.U., Foster, T.U., 1976. Residues of atrazine (2-chloro-4-ethylamino-6-isopropylamino-S-triazine) and its metabolites in chicken tissues. J. Agric. Food Chem. 24, 768-771.

Lichtenstein, E.P., Kunstman, J.1., Fuhremann, 
T.W., Liang, T.T., 1979. Effects of atrazine on the toxicity penetration and metabolism of carbofuran in the house fly. J. Econ. Entomol. 72, 785-789.

Lichtenstein, E.P., Liang, T.T., Anderegg, B.N., 1973. Synergism of insecticides by herbicides. Science 181, 847-849.

McCarty, L.S., Ozburn, G.W., Smith, A.D., Dixon, D.G., 1992. Toxicokinetic modeling of mixtures of organic chemicals. Environ. Toxicol. Chem. 11, 1037-1047.

Siegfried, B.D., Mullin, C.A., 1988. Properties of a cytochrome P-451 dependent epoxidase in aldrin-resistant western corn rootworm. Diabrotica virgifera virgifera leConte, Pestic. Biochem. Physiol. 31, 261-268.

Solomon, K.R., Baker, D.B., Richards, R.P., Dixon, K.R., Klaine, S.J., La Point, T.W., Kendall, R.J., Weisskopf, C.P., Giddings, J.M., Giesy, J.P., Hall Jr., L.W., Williams, W.M., 1996. Ecological risk assessment of atrazine in North American surface waters. Environ. Toxicol. Chem. 15, 31-76.

Sundseth, S.S., Kennel, S.J., Waters, L.C., 1989. Monoclonal antibodies to resistance-related forms of cytochrome in P450 Drosophila melanogaster. Biochem. Physiol. Pestic. 33, 176188.

Terriere, L., 1984. Induction of detoxification enzymes. Ann. Rev. Entomol. 29, 71-88.
Thomas, P.E., Ryan, D., Levin, W., 1976. An improved staining procedure for the detection of the peroxidase activity of cytochrome P-450 on sodium dodecyl sulfate polyacrylamide gels. Anal. Biochem. 75, 168-176.

Thurman, E.M., Goolsby, D.A., Meyer, M.J., Mills, M.S., Pomes, M.L., Kolpin, D.W., 1992. A reconnaissance study of herbicides and their metabolites in surface water of the Midwestern United States using immunoassay and gas chromatography/mass spectrometry. Environ. Sci. Technol. 26, 2440-2447.

Pape-Lindstrom, P.A., Lydy, M.J., 1997. Synergistic toxicity of atrazine and organophosphate insecticides contravenes the response addition mixture model. Environ. Toxicol. Chem. 16, 2415-2420.

Welton, F., Aust, S.D., 1974. Multiplicity of cytochrome P-450 hemoproteins in rat liver microsomes, Preparation and specificity of an antibody to the hemoprotein induced by phenobarbital, Biochem. Biophys. Res. Commun. 56, 898-906.

Wilkinson, C.F., Brattsten, L.B., 1972. Microsomal drug metabolizing enzymes in insects. Drug Metabolism Rev. 1, 153-228.

Ugazio, G., Bosio, A., Nebbia, C., Soffietti, M.G., 1991. Age and sex related effects on hepatic drug metabolism in rats chronically exposed to dietary atrazine. Res. Commun. Chrm. Pathol. Pharmacol. 73, 231-243. 